\title{
Neonatal Risks of Vitamin D and Iodin Supplementations during Pregnancy
}

\author{
Catherine Lecoq1, Raphael Serreau ${ }^{2 *}$ (1) \\ ${ }^{1}$ Midwife School Sorbonne Medicine University, Saint-Antoine Hospital, Paris, France \\ ${ }^{2}$ PARADICT-O Clinical Research Unit Orleans Metropole, EA INSERM Psycomadd, South Saclay Paris University, Paris, France \\ Email: ^raphael.serreau@orleans-metropole.fr
}

How to cite this paper: Lecoq, C. and Serreau, R. (2019) Neonatal Risks of Vitamin D and Iodin Supplementations during Pregnancy. Open Journal of Obstetrics and Gynecology, 9, 1443-1455.

https://doi.org/10.4236/ojog.2019.911140

Received: October 9, 2019

Accepted: November 4, 2019

Published: November 7, 2019

Copyright $\odot 2019$ by author(s) and Scientific Research Publishing Inc. This work is licensed under the Creative Commons Attribution International License (CC BY 4.0).

http://creativecommons.org/licenses/by/4.0/

\begin{abstract}
Background: The consumption of dietary supplements (DS) has increased by almost $10 \%$ last decade. This trend may be true also for pregnant women; however, it was reported that pregnant women do not sufficient and correct knowledge on nutritional needs during pregnancy. Thus, we here attempted to determine the French situation of how French pregnant women take DS and its social-clinical significance using questionnaires, with special reference to vitamin D (VD) overtaking. Materials and Methods: A prospective multi-centric study was performed in three maternities in Paris. One hundred-fifty questionnaires were administered to pregnant women by midwife. Results: Thirty-four patients were interviewed at the maternity ward of the Deaconesses, 61 at the Pitié-Salpêtrière and 55 at Armand Trousseau. During pregnancy, DS started mainly during the first trimester. Frequently, doctors initially prescribe them and women tended to continue to take them thereafter. Possible VD overdosage was observed. Conclusion: We here characterized French pregnant women in terms of DS during pregnancy and also, to our knowledge, for the first time emphasized the risk of vitamin D overdose during pregnancy in France. However, since the cumulative dose throughout the pregnancy was not determined here, definite conclusion of whether women really take overdose of this supplement may not be made. Women of higher socio-professional society tended to consume more DS during pregnancy, and, thus, further monitoring may be needed especially to this fraction of pregnant women.
\end{abstract}

\section{Keywords}

Dietary Supplement (DS), Pregnancy, Hypercalcemia, Vitamin D (VD), Iodine 


\section{Introduction}

In less than a decade, the consumption of food supplements has increased by almost 10\% [1] [2]. Dietary supplements of pregnancy have been implicated in cases of hypercalcemia and neonatal hypothyroidism [3]. In pregnant women, as well as in the general population, energy intakes are recommended as: 55\% of carbohydrates, $30 \%-35 \%$ of lipids and $10 \%-15 \%$ of proteins [4] [5]. Folic acid needs to be supplemented in the pre-conception period and until the end of the first trimester and in vitamin D at the 6th [5] [6]. No supplementation is needed for other vitamins [4] [7]. Knowledge needs to be emphasized in pregnant women about nutritional needs during pregnancy [8]. Taking medication during pregnancy can affect the fetus so pregnant women need to ask a health professional (midwife, doctor, pharmacist) before taking any pills or drugs [9] [10].

The dietary supplement (DS) is defined by Decree No. 2006-352 of 20 March 2006 [11]. Nutrient deficiencies are rare in the general population except for vitamin $\mathrm{D}$, where nearly $50 \%$ of the general populations are in deficit [12] [13]. The midwives, doctors and pharmacists should be aware of the risk of neonatal hypercalcemia after vitamin D supplementation during pregnancy [14]-[19].

National College of Gynecologists-Obstetricians (CNGOF) in 1997 and the National Agency for Sanitary Safety, Food, Environment, Work (ANSES) have recommended to monitor the DS in their real conditions of use and identifies adverse effects [20] [21]. They study the consumption of DS since 1998 and during the period 2006-2007 that shown $20 \%$ of adults have consumed (DS), twice in women (26.5\%) than in men (12.6\%). Consumers generally have a high level of education. At the national level, there is higher consumption in the South and East 22\% against 18\% in the North and West. The motivation for the purchase is mainly due to the prescription or advice from a health professional (58\%), the place of purchase is mainly in pharmacy (54\%) and rarely on the internet (1\%). The main expectations of consumers are: "fight against fatigue" (33\%), "solve a health problem" (21\%), "stay healthy/fight against diseases" (17\%). Among women, $6 \%$ of consumers say they consume it to meet the needs related to pregnancy. Finally, "balancing one's current diet" and "supplementing insufficient dietary intake" only account for $3 \%$ and $2 \%$ of motivations. The study shows that DS intake is influenced by the seasons, more important in winter than during the summer [1].

In June 2017, the INCA 3 study is published. It was conducted over the 20142015 period. Compared to the previous study, there is an increase in DS consumption (from $20 \%$ to $29 \%$ ). The main place of purchase is still the pharmacy (45\%) but the purchase by internet has grown strongly from $1 \%$ to $11 \%$. Women, people with a high level of education and seasonality are consistent characteristics in DS consumption. We know that the main consumers are 18 to 44 years old [2].

The selling price of the DS is not regulated. His purchase therefore represents 
a certain budget. This is why the studies found on the subject are on populations from favored countries. A study conducted in the United States, Germany, Sweden and Finland shows that pregnancy DS consumption is associated in all countries with primiparity; on the other hand, women under 25 years old are less likely to be users. Some factors such as high level of education are found in the United States and Sweden but not in Finland and Germany. Tobacco use is associated with lower turnover in the Nordic countries, the United States and Germany, but this factor is not significant. In Finland, alcohol consumption during pregnancy and pathological first-trimester markers are related to an increase in DS consumption. This can be explained by a probable representation of the DS which differs according to the countries. In Finland, where consumption is increased in the event of a "pejorative" event for pregnancy (pathological serum markers, tobacco consumption) the DS would be represented as a remedy that could combat these derogatory events. In Sweden and Germany, overweight people (body mass index $(\mathrm{BMI})>25 \mathrm{~kg} / \mathrm{m}^{2}$ ) tend to use less DS. Finally, in the United States, where ethnicity studies are permitted, there is no link with pregnancy DS consumption [22].

A study conducted in Saudi Arabia shows that the use of pregnancy DS was very high $(71.5 \%)$. Factors such as education level, household income, having 1 or 2 children are associated with DS consumption. BMI, professional activities do not affect consumption. $81.6 \%$ of respondents believe that supplementation is important and that neonatal outcomes are better and the study shows that there is no association. Consumers take a majority of DS following the advice of their doctor (65.7\%) [23].

We have seen that many pregnancy DS consumption factors and DS more generally are common as the socioeconomic level. Some parameters were found to be consumption factors in some countries but not in others (tobacco). Now we will see the situation in France. A cohort study conducted in 2013, showed that the use of dietary supplements of pregnancy in France was increased if these factors were present: primiparity (relative risk (RR): 2 to 3 ), to have high incomes (>3130 €/month) (RR: 2.09), live in the Paris region (RR 2 to 4 according to other French regions), be from a higher socio-professional category (RR: 2 by contribution to the unemployed). On the other hand, age, marital status, level of education, knowledge of PNNS recommendations and consumption of organically produced foods are not significantly related to pregnancy DS consumption. Use of DS during pregnancy follows a prescription or recommendation by a physician in $86.7 \%$ of cases [24].

In February 2007, the French Agency for Sanitary Safety of Foods (AFSSA), published recommendations (RDAs) for folic acid and vitamin $\mathrm{D}$ and for claims claimed by a dietary supplement as intended for pregnant women. The opinion states that vitamin B9 intake should not be continued beyond the first trimester of pregnancy, which is in line with the recommendations in force. Regarding the vitamin D intake, the intake of $400 \mathrm{IU} /$ day (10 $\mu \mathrm{g} /$ day) is in agreement with the 
recommendations. Iodine contributions must be found in the foods rich in iodine (milk and dairy products, crustaceans, eggs, enriched salt...) and that only the patients at high risk (geographical area deficiency, smoking...) are likely to have drug supplementation throughout the pregnancy. For iron, the AFSSA recalls that women must be supplemented in cases of iron deficiency anemia and systematic supplementation is not justified, and that the ideal to prevent anemia is to have a varied diet and balanced. Finally, the AFSSA says that these DS are not adapted to the nutritional needs of all pregnant women without distinction and adds that the information leaflets should draw attention to the risks of simulation induced by the DS and other enriched foods and the consumption of several products was discouraged [25].

In May 2017, ANSES described 84 cases reports about DS adverse reactions during pregnancy [3]. Eighteen were imputable. The adverse effects are mainly hypercalcemia and neonatal hypothyroidism. 2 cases were strongly imputable, eleven cases of possible accountability, and five cases of questionable accountability. ANSES confirmed that 5 cases of neonatal hypercalcemia and 2 cases of neonatal hypothyroidism where DS would be involved. In reported cases, DS were not the only source of vitamin D or iodine. ANSES informed pregnant women to be advised by a health professional on the use of DS during pregnancy.

\section{Material \& Method}

The study focused on the population of patients giving birth in the 12th and 13th districts of Paris. Indeed, there are maternities of different types, public and private of collective interest.

The expected number of patients surveyed is at least 134 in total, to have significant results.

The distribution of the workforce varies according to the type of maternity. That is $23 \%$ of patients interviewed in type 1, $40 \%$ in type 2 and $37 \%$ in type 3 , as observed in the 2016 national perinatal survey [26]. All patients were asked about their living conditions and the course of their pregnancy, including the recommended supplements. Patients who consumed DS had additional questions about their use of these products, their use during this pregnancy.

The inclusion criteria were French language comprehension, she had to have given birth for at least 24 hours. The criteria for non-inclusion were that the patient was in the service of the diaper suites but had not given birth (patient being tripped); patients who cannot communicate orally in French (foreign patients who do not speak French, hearing-impaired patients who cannot communicate otherwise than by sign language).

Studied variables were: age, gestity, parity, BMI, geographical origin/nationality, socio-professional category and marital status. These data are compared to the 2016 national perinatal survey to find out to what extent the model of this population can be generalized to the French population. The profile of consumers 
were: socio-professional category, marital status, type of housing, eating habits, diet, physical activity, consumption of alcohol and other drugs, geographic origin/nationality, age, BMI, presence of chronic disease. The variables which could affect the intake of dietary supplements were: the professional following the pregnancy in the first 6 months, a pregnancy spontaneously obtained, the type of pregnancy, the discovery of a pathology during pregnancy, taking vitamin $\mathrm{D}$ in the 6th month and peri-conceptional folic acid, performing prenatal and parenting preparation (PNP) and early prenatal care (EPP). The variables which could affect the dietary supplements consumption during pregnancy, use outside pregnancy, consumption, the beginning of the consumption of the DS, an interruption of the taking of these, and the reason for stopping, the average time of use if it was interrupted, the reason for taking the DS and the place of purchase.

Student's T test was used when the values used were averages and Chi-square tests when the values found are ratios. The Student test was performed with the software included in Excel $^{\circledR}$. For Chi 2 tests, calculations were performed with the Open-Épi ${ }^{\oplus}$ software. The alpha risk was set at 0.05 and the confidence intervals are at $95 \%$.

\section{Results}

The study was conducted from November 16, 2018 to January 23, 2019. The total number of patients that could be included in the study was 150 . The questionnaire was distributed in 3 maternity homes in the East of Paris: The Deaconesses (type 1), La Pitié-Salpêtrière (type 2), and Armand Trousseau (type 3). Thirty-four patients were interviewed at the maternity ward of the Deaconesses, 61 at the Pitié-Salpêtrière and 55 at Armand Trousseau.

Pregnancy supplements were found to start mainly during the first trimester $(\mathrm{p}<0.000001)$. Following a medical prescription $(\mathrm{p}=0.0001)$ and the prescriber was usually a gynecologist-obstetrician $(\mathrm{p}=0.000008)$ with a prescription $(\mathrm{p}<$ $0.0000001)$. Other prescribers were general practitioners, midwives and nutritionists.

DS was mainly advised by a pharmacist $(\mathrm{p}=0.014)$.

Finally, in patients who consumed dietary supplements until the end of pregnancy, 2 started in the second trimester and 3 during the third trimester. In these patients, all had taken the recommended dose of vitamin $\mathrm{D}$, so the $2 \mathrm{pa}$ tients who started in the second trimester may be considered at risk for vitamin D overdose.

\section{Discussion}

This is, to our knowledge, the first report on the risk of vitamin D overdose during pregnancy in France Regarding the risk of vitamin D overdose; this is the first study to address this risk.

As a first step, we will see if the surveyed population corresponds to the model 
of patients having a pregnancy in France, then we will see if the profile of the consumers of dietary supplements of pregnancy is different from that of the consumers of the general population. Finally, we will see if our study finds the same characteristics in consumers than in the National Perinatal Survey 2016 [26].

The proportion of patients of French origin is lower in this population than at national level (48\% vs. $81.4 \%$ ) and the same is true for French nationality $(79.3 \%$ vs. $85.9 \%$ ) (Table 1). This can be explained by the fact that historically, the Paris basin is a place of arrival of different waves of immigration. Regarding the marital status of patients, there is a much larger share of married patients compared to the French population ( $52 \%$ vs. $42.2 \%$ ). In contrast, there is a smaller share of PACS (14.7\% vs 41.3). In the 2016 Perinatal Survey, marital patients were not included and were included in the single category. However, when we look at the percentage of couples "not living in a couple" which corresponds to the share of singles, the percentage is $5.2 \%$ which is similar to the $4.7 \%$ observed in this study.

For the socio-professional categories, there is a very large share of senior managers and intellectual professions (32.7\% vs. $13.3 \%)$. This is explained by the fact that Paris is an economic engine of France and that many large companies are headquartered in Paris or La Défense, the business district. Given the location of the study, as well as the specificity of the Paris region, it seems difficult to expand the results obtained at a national level (Table 2).

Table 1. Population baseline.

\begin{tabular}{|c|c|c|c|c|c|c|c|}
\hline & Population & $\begin{array}{c}\text { Diaconesses } \\
\text { Hospital }\end{array}$ & $\mathrm{p}$ & Pitié Hospital & $\mathrm{p}$ & $\begin{array}{c}\text { Trousseau } \\
\text { Hospital }\end{array}$ & $\mathrm{p}$ \\
\hline $\mathrm{n}$ & 150 & 34 & & 61 & & 55 & \\
\hline Age & $32.1[31.8-32.8]$ & $33.9[32.4-35.3]$ & 0.03 & $30.3[29.6-31.3]$ & 0.003 & $33.1[31.9-34.2]$ & 0.166 \\
\hline Gestity & $2.1[1.9-2.3]$ & $2.2[1.7-2.7]$ & 0.702 & $1.9[1.7-2.2]$ & 0.283 & $2.2[1.9-2.6]$ & 0.525 \\
\hline Parity & $1.7[1.6-1.8]$ & $1.7[1.3-2.0]$ & 0.956 & $1.7[1.4-1.9]$ & 0.917 & $1.7[1.5-1.9]$ & 0.868 \\
\hline BMI & $23.8[23.0-24.8]$ & 22.8 [21.7 - 23.9] & 0.146 & $24.5[23.1-25.9]$ & 0.392 & $23.6[22.5-24.8]$ & 0.821 \\
\hline Patients & $72 / 150(48 \%)$ & $23 / 34$ & 0.04 & $22 / 61$ & 0.117 & $27 / 55$ & 0.891 \\
\hline French nationality & $119 / 150(79.3 \%)$ & $32 / 34$ & 0.03 & $45 / 61$ & 0.385 & $42 / 55$ & 0.643 \\
\hline \multicolumn{8}{|c|}{ Marital status } \\
\hline Married & $78 / 150(52 \%)$ & $20 / 34$ & 0.480 & $30 / 61$ & 0.7133 & $28 / 55$ & 0.891 \\
\hline Single & $7 / 150(4.7 \%)$ & 0 & 0.233 & $5 / 61$ & 0.3379 & $2 / 55$ & 0.801 \\
\hline PACS & $22 / 150(14.7 \%)$ & $5 / 34$ & 0.966 & $8 / 61$ & 0.7902 & $9 / 55$ & 0.754 \\
\hline Marital life & $43 / 150(28.7 \%)$ & $9 / 34$ & 0.815 & $18 / 61$ & 0.8966 & $16 / 55$ & 0.945 \\
\hline \multicolumn{8}{|c|}{ Socio-professional categories } \\
\hline Liberal activities & $7 / 150$ (4.7\%) & $2 / 34$ & 0.739 & $3 / 61$ & 0.911 & $2 / 55$ & 0.801 \\
\hline
\end{tabular}


Table 2. Dietary supplement status.

\begin{tabular}{|c|c|c|c|}
\hline & DS users & Non users & $\mathrm{p}$ \\
\hline $\mathrm{n}$ & 59 & 91 & \\
\hline French origin & $31 / 59$ & $41 / 91$ & 0.376 \\
\hline French nationality & $50 / 59$ & $69 / 91$ & 0.194 \\
\hline \multicolumn{4}{|c|}{ Marital status } \\
\hline Married & $32 / 59$ & $46 / 91$ & 0.861 \\
\hline Single & $1 / 59$ & $6 / 91$ & 0.189 \\
\hline PACS & $10 / 59$ & $0 / 91$ & 0.00005 \\
\hline Marital life & $16 / 59$ & $27 / 91$ & 0.744 \\
\hline \multicolumn{4}{|c|}{ Socio-Professional category } \\
\hline Liberal activities & $2 / 59$ & $5 / 91$ & 0.593 \\
\hline Third sector activities & $23 / 59$ & $26 / 91$ & 0.03 \\
\hline Intermediate profession & $18 / 59$ & $25 / 91$ & 0.690 \\
\hline Employee & $12 / 59$ & $25 / 91$ & 0.331 \\
\hline No professional activity & $4 / 59$ & $10 / 91$ & 0.4083 \\
\hline Professional activity during pregnancy & $47 / 59$ & $67 / 91$ & 0.408 \\
\hline \multicolumn{4}{|c|}{ Habitation status } \\
\hline Personal habitation & $58 / 59$ & $84 / 91$ & 0.123 \\
\hline Relatives & 0 & $5 / 91$ & 0.079 \\
\hline Hostel & $1 / 59$ & $2 / 91$ & 0.879 \\
\hline \multicolumn{4}{|c|}{ Food status } \\
\hline Food variety and equilibre & $49 / 59$ & $82 / 91$ & 0.219 \\
\hline Junk-food & $7 / 59$ & $4 / 91$ & 0.105 \\
\hline Pesco-vegan & $1 / 59$ & $1 / 91$ & 0.787 \\
\hline Vegan & $2 / 59$ & $4 / 91$ & 0.797 \\
\hline
\end{tabular}

Higher socio-professional category consumed more DS than general population. Prescription was the main motivation for taking DS [24].

This study showed that follow-up by a gynecologist-obstetrician was associated with an increase in DS intake, contrary to pregnancies followed by midwives in maternity where patients do not consume dietary supplements. It should be noted that in the literature no study has been done on the practice of prescriptions by midwives and in particular on the prescription of vitamins during pregnancy.

The literature is not unanimous on certain criteria that may influence the consumption of DS such as smoking, marital status. No smoking status before pregnancy and PACS were associated with an increase in DS intake.

In this study, a very small proportion (2/59) of patients were aware of a potential risk of overdose. Although the patients are not very aware of this risk, we will specifically study the case of folic acid (vitamin B9), vitamin D and iodine. Folic acid: Scientific authorities recommend peri-conception vitamin B9 supple- 
mentation to prevent neural tube closure abnormalities. This supplementation can be provided by food by increasing the consumption of folate-rich foods such as green vegetables and if not, a supplementation of 100 to $200 \mu \mathrm{g} / \mathrm{day}$ can be made. Vitamin B9, in patients without consuming food supplements, a third (27/91) had not received folic acid peri-conception or during the first trimester after pregnancy known. Some begin their consumption during the peri-conception period. A large proportion of these women also took folic acid in the first trimester (32/45). The recommendations are that the intake should be $200 \mu \mathrm{g}$ per-conceptional. Patients take 4 times the dose because the majority of food supplements on the market are dosed at $400 \mu \mathrm{g}$ and practitioners also prescribe $400 \mu \mathrm{g}$ of folic acid since no drug is dosed at $200 \mu \mathrm{g}$. In addition, for people with an antecedent neural tube closure abnormality it is recommended to supplement them with $5 \mathrm{mg}$ /day of folic acid 1 month before the beginning of pregnancy and up to 2 months of pregnancy. These doses are well above the 800 $\mu \mathrm{g} / \mathrm{d}$ that can be taken by patients taking dietary supplements and the folic acid that has been prescribed (Table 3). Finally, from a metabolic point of view, vitamin B9 is a water-soluble vitamin and in the case of high consumption, it is eliminated mainly in faeces and in a smaller quantity in the urine [19]. Thus the amounts of folic acid absorbed and circulating are quite low.

The recommended vitamin $\mathrm{D}$ intake during pregnancy was the single dose of a 100,000 IU ampoule at the beginning of the 7th month. Or daily intake of 400 IU from the beginning of pregnancy or $1000 \mathrm{IU} /$ day at the beginning of the third quarter, but these types of patterns are more restrictive [20]. In non-consuming patients, almost three-quarters (70/91) of them had the recommended vitamin D supplementation.

As previously stated, overdosed patient with vitamin $\mathrm{D}$ was defined with pregnancy supplements for the duration of her pregnancy and having received a vitamin D ampoule dosed at 100,000 IU at the beginning of the 7 th month or at another time of pregnancy. In this study, this proportion represents more than $3 / 4$ of the patients. Thus, it was important to be vigilant to a possible over consumption of vitamin D with DS. ANSES reports 5 cases of neonatal hypercalcemia where the implication of dietary supplements of pregnancy is doubtful or possible. These cases could be treated by stopping the administration of vitamin $\mathrm{D}$ in the newborn. Indeed, according to the current pediatric recommendations, infants should receive up to 18 months of 800 to $1200 \mathrm{IU}$ of vitamin D per day [6]. We can thus understand that if we take every day of her pregnancy a dose of vitamin $\mathrm{D}$, it was stored in the adipose tissue mainly constituted during the first part of the pregnancy and therefore that the day of the taking of 100,000 IU prescribed, the patient is quickly overdosed. Vitamin D contained in pregnancy food supplements has been implicated in cases of overdose [27] [28] [29] [30].

ANSES, in its May 2017 report, recalls that there have been two cases of congenital hypothyroidism where the involvement of dietary supplements is possible. Thus, since this alert was issued, all notices were updated. 
Table 3. Comparison pregnancy status and dietary supplementation.

\begin{tabular}{|c|c|c|c|}
\hline & DS users & Non users & $\mathrm{p}$ \\
\hline $\mathrm{n}$ & 59 & 91 & \\
\hline Age (mean) & $32.6[31.0-34.2]$ & $31.8[30.9-32.7]$ & 0.246 \\
\hline Primiparity & $32 / 59$ & $48 / 91$ & 0.861 \\
\hline Multipare & $27 / 59$ & $43 / 91$ & 0.861 \\
\hline BMI (mean) & $24.3[23.0-25.6]$ & $23.5[11.5-13.5]$ & 0.316 \\
\hline Tobacco (non users) & $51 / 59$ & $65 / 91$ & 0.032 \\
\hline Alcohol (non users) & $54 / 59$ & $87 / 91$ & 0.3321 \\
\hline Weight gain during pregnancy & $12.5[10.8-14.2]$ & $12.5[11.5-13.5]$ & 0.902 \\
\hline No Sport practice during pregnancy & $27 / 59$ & $45 / 91$ & 0.664 \\
\hline Sport practice during pregnancy & $20 / 59$ & $27 / 91$ & 0.589 \\
\hline No chronical diseases & $45 / 59$ & $74 / 91$ & 0.463 \\
\hline No infertility & $54 / 59$ & $81 / 91$ & 0.638 \\
\hline Pregnancy plan & $57 / 59$ & $80 / 91$ & 0.066 \\
\hline Single pregnancy & $57 / 59$ & $90 / 91$ & 0.400 \\
\hline \multicolumn{4}{|c|}{ Professional status } \\
\hline Physician & $1 / 59$ & $6 / 91$ & 0.189 \\
\hline Gyneco-obstetrician & $48 / 59$ & $56 / 91$ & 0.010 \\
\hline Private activity & $35 / 59$ & $40 / 91$ & 0.069 \\
\hline In maternity ward & $13 / 59$ & $16 / 91$ & 0.506 \\
\hline Mide-wife & $10 / 59$ & $27 / 91$ & 0.079 \\
\hline Private activity & $5 / 59$ & $6 / 91$ & 0.672 \\
\hline In maternity ward & $5 / 59$ & $21 / 91$ & 0.020 \\
\hline PMI & $0 / 59$ & $2 / 91$ & 0.366 \\
\hline \multicolumn{4}{|c|}{ Gestational diabetis } \\
\hline Yes & $9 / 59$ & $20 / 91$ & 0.319 \\
\hline Regime & $3 / 59$ & $8 / 91$ & 0.423 \\
\hline With insuline & $6 / 59$ & $12 / 91$ & 0.598 \\
\hline Without insuline & $50 / 59$ & $71 / 91$ & 0.319 \\
\hline Other diseases during pregnancy & $46 / 59$ & $73 / 91$ & 0.734 \\
\hline PNP activity & $40 / 59$ & $50 / 91$ & 0.121 \\
\hline EPP activity & $21 / 59$ & $23 / 91$ & 0.183 \\
\hline \multicolumn{4}{|c|}{ Dietary supplement (DS) } \\
\hline Vitamin D during pregnancy & $47 / 59$ & $70 / 91$ & 0.517 \\
\hline Folic acid supplement during the first trimester during pregnancy & $42 / 59$ & $64 / 91$ & 0.916 \\
\hline During peri conceptus & $20 / 59$ & $22 / 91$ & 0.204 \\
\hline After pregnancy beginning & $22 / 59$ & $42 / 91$ & 0.290 \\
\hline No folic acid supplementation & $17 / 59$ & $27 / 91$ & 0.916 \\
\hline
\end{tabular}


This study was able to show that the profile of women who consume pregnancy supplements was similar to the general population of these consumers. The proportion of these people is around $40 \%$ in the study population. DS consumption was made mainly during the first trimester and part of this population continues throughout the pregnancy. These food supplements was overwhelmingly prescribed by gynecologists-obstetricians and purchased in pharmacies. A relatively small number of patients were aware of the risk of overdose [28]. Recommendations need to be updated with new vegan and vegeterian habits during pregnancy.

\section{Conclusion}

This is, to our knowledge, the first report on the risk of vitamin D overdose during pregnancy in France. However, since the cumulative dose throughout the pregnancy was not determined here, definite conclusion of whether women really take overdose of this supplement may not be made. Women of higher socio-professional society tended to consume more DS during pregnancy, and thus further monitoring may be needed especially to this fraction of women.

\section{Conflicts of Interest}

The authors declare no conflicts of interest regarding the publication of this paper.

\section{References}

[1] Bénetier, C., Bertin, M., Calamassi-Tran, G., Dubuisson, C., Dufour, A., Gauchard, F., Lafay, L., Lioret, S. and Touvier, M. (2009) Etude Individuelle Nationale des Consommations Alimentaire (INCA 2) 2006-2007. AFSSA.

[2] Huneau, J.F., Feidt, C., Bergis, H., Blanchemanche, S., Caillavet, F., Charles, M.A., Christine, M., Duche, P., Saillard, P., Sauvant-Rochat, M.P. and Walrand, S. (2017) Étude individuelle nationale des consommations alimentaires 3 (INCA 3). Avis de l'ANSES Rapport d'expertise collective juin 2017.

[3] Maciuk, A., Atlan, C., Boutefnouchet, S., Champy, P., Crenn, P., Hennebelle, T., Le Garrec, R., Renaudin, J.M., Vuitton, D.A., Weniger, B. and Zazzo, J.F. (2017) Risques endocriniens et métaboliques relatifs à l'apport au cours de la grossesse de vitamine $\mathrm{D}$ et d'iode par des compléments alimentaires impliqués dans des cas de nutrivigilance. ANSES.

[4] Zein, S., Rachidi, S., Shami, N., Sharara, I., Cheikh-Ali, K., Gauchez, A.S., Moulis, J.M., Ayoubi, J.M., Salameh, P. and Hininger-Favier, I. (2017) Association between Iron Level, Glucose Impairment and Increased DNA Damage during Pregnancy. Journal of Trace Elements in Medicine and Biology, 43, 52-57. https://doi.org/10.1016/j.jtemb.2016.11.006

[5] Radetti, G., Zavallone, A., Gentili, L., Beck-Peccoz, P. and Bona, G. (2002) Foetal and Neonatal Thyroid Disorders. Minerva Pediatrica, 54, 383-400.

[6] Bianchi, C.M., Mariotti, F., Lluch, A., Journet, C., Stehr, Y., Beaussier, H., Fournier, J., Dervaux, S., Cohen-Tanuggi, D., Reulet, E., Verger, E.O., Azria, E. and Huneau, J.F. (2019) Computer-Based Tailored Dietary Counseling Improves the Nutrient Adequacy of the Diet of French Pregnant Women: A Randomized Controlled Trial. 
British Journal of Nutrition, 18, 1-24. https://doi.org/10.1017/S0007114519002617

[7] Maden, M. (2001) Vitamin A and the Developing Embryo. Postgraduate Medical Journal, 77, 489-491. https://doi.org/10.1136/pmj.77.910.489

[8] Jacovetti, C. and Regazzi, R. (2012) Metabolic Adaptations during Pregnancy. Médecine des Maladies Métaboliques, 6, 279-287. https://doi.org/10.1016/S1957-2557(12)70415-7

[9] Thangaratinam, S., Rogozinska, E., Jolly, K., Glinkowski, S., Roseboom, T., Tomlinson, J., et al. (2012) Effects of Interventions in Pregnancy on Maternal Weight and Obstetric Outcomes: Meta-Analysis of Randomised Evidence. British Medical Journal, 344, e2088. https://doi.org/10.1136/bmj.e2088

[10] Krzepota, J. and Putek-Szelag, E. (2014) Nutritional Habits in the Light of General Health Behaviours of Pregnant Women. Annals of Agricultural and Environmental Medicine, 21, 425-428. https://doi.org/10.5604/1232-1966.1108618

[11] République Française (2006) Décret n 2006-352 du 20 mars 2006 relatif aux compléments alimentaires. JORF No. 72, 4543.

[12] Butte, N.F. and King, J.C. (2005) Energy Requirements during Pregnancy and Lactation. Public Health Nutrition, 8, 1010-1027. https://doi.org/10.1079/PHN2005793

[13] Vernay, M., Sponga, M., Salanave, B., Amivi, O., Deschamps, V., Malon, A. and Castetbon, K. (2012) Statut en vitamine D de la population adulte en France: l'Etude Nationale Nutrition Santé (ENNS 2006-2007). BEH, 189-194.

[14] Hureaux, M., Molin, A., Jay, N., Saliou, A.H., Spaggiari, E., Salomon, R., Benachi, A., Vargas-Poussou, R. and Heidet, L. (2018) Prenatal Hyperechogenic Kidneys in Three Cases of Infantile Hypercalcemia Associated with SLC34A1 Mutations. Pediatric Nephrology, 33, 1723-1729. https://doi.org/10.1007/s00467-018-3998-Z

[15] Jones, G., Kottler, M.L. and Schlingmann, K.P. (2017) Genetic Diseases of Vitamin D Metabolizing Enzymes. Endocrinology and Metabolism Clinics of North America, 46, 1095-1117. https://doi.org/10.1016/j.ecl.2017.07.011

[16] Vogiatzi, M.G., Jacobson-Dickman, E. and DeBoer, M.D. (2014) Drugs, and Therapeutics Committee of The Pediatric Endocrine Society. Vitamin D Supplementation and Risk of Toxicity in Pediatrics: A Review of Current Literature. The Journal of Clinical Endocrinology \& Metabolism, 99, 1132-1141. https://doi.org/10.1210/jc.2013-3655

[17] Reynolds, A., O’Connell, S.M., Kenny, L.C. and Dempsey, E. (2017) Transient Neonatal Hypercalcaemia Secondary to Excess Maternal Vitamin D Intake: Too Much of a Good Thing. BMJ Case Reports, 2017, bcr-2016-219043.

https://doi.org/10.1136/bcr-2016-219043

[18] Roth, D.E., Morris, S.K., Zlotkin, S., Gernand, A.D., Ahmed, T., Shanta, S.S., Papp, E., Korsiak, J., Shi, J., Islam, M.M., Jahan, I., Keya, F.K., Willan, A.R., Weksberg, R., Mohsin, M., Rahman, Q.S., Shah, P.S., Murphy, K.E., Stimec, J., Pell, L.G., Qamar, H. and Al Mahmud, A. (2018) Vitamin D Supplementation in Pregnancy and Lactation and Infant Growth. The New England Journal of Medicine, 379, 535-546. https://doi.org/10.1056/NEJMoa1800927

[19] Roth, D.E., Al Mahmud, A., Raqib, R., Akhtar, E., Perumal, N., Pezzack, B. and Baqui, A.H. (2013) Randomized Placebo-Controlled Trial of High-Dose Prenatal Third-Trimester Vitamin D3 Supplementation in Bangladesh: The AViDD Trial. Nutrition Journal, 12, 47. https://doi.org/10.1186/1475-2891-12-47

[20] CNGOF (1997) Supplémentation au cours de la grossesse, Recommandations pour 
la pratique clinique.

[21] Anses (2019) Agence nationale de sécurité sanitaire de l'alimentation, de l'en-vironnement et du travail. La nutrivigilance, qu'est-ce que c'est? https://www.anses.fr/fr/content/la-nutrivigilance-quest-ce-que-cest

[22] Aronsson, C.A., Vehik, K., Yang, J., Uusitalo, U., Hay, K., Joslowski, G., Riikonen, A., Ballard, L., Virtanen, S.M. and Norris, J.M. (2013) TEDDY Study Group. Use of Dietary Supplements in Pregnant Women in Relation to Sociodemographic Factors-A Report from The Environmental Determinants of Diabetes in the Young (TEDDY) Study. Public Health Nutrition, 16, 1390-1402. https://doi.org/10.1017/S1368980013000293

[23] Alfawaz, H.A., Khan, N., AlOteabi, N., Hussain, S.D. and Al-Daghri, N.M. (2017) Factors Associated with Dietary Supplement Use in Saudi Pregnant Women. Reproductive Health, 14, 104. https://doi.org/10.1186/s12978-017-0357-7

[24] Pouchieu, C., Lévy, R., Faure, C., Andreeva, V.A., Galan, P., Hercberg, S., et al. (2013) Socioeconomic, Lifestyle and Dietary Factors Associated with Dietary Supplement Use during Pregnancy. PLoS ONE, 8, e70733. https://doi.org/10.1371/journal.pone.0070733

[25] AFSSA (2007) Avis de l'agence française de sécurité sanitaire des aliments relatif à l'évaluation concernant le dépassement des apport journaliers recommandés (AJR) concernant l'acide folique (B9) et la vitamine $\mathrm{D}$ et des allégations revendiquées par un complément alimentaire présenté comme destiné aux femmes enceintes ou allaitantes.

[26] Zeitlin, J., Szamotulska, K., Drewniak, N., Mohangoo, A.D., Chalmers, J., Sakkeus, L., Irgens, L., Gatt, M., Gissler, M., Blondel, B. and the Euro-Peristat Preterm Study Group (2013) Preterm Birth Time Trends in Europe: A Study in 19 Countries. BJOG: An International Journal of Obstetrics \& Gynaecology, 120, 1356-1365. https://doi.org/10.1111/1471-0528.12281

[27] Tort, J., Lelong, N., Prunet, C., Khoshnood, K. and Blondel, B. (2013) Maternal and Health Care Determinants of Preconceptional Use of Folic Acid Supplementation in France: Results from the 2010 National Perinatal Survey. BJOG: An International Journal of Obstetrics \& Gynaecology, 120, 1661-1667. https://doi.org/10.1111/1471-0528.12414

[28] Rigourd, V., Dridi Brahim, I., Smii, S., Razafimahefa, H., Quetin, F., Leroy, E., Pichon, C., Giuseppi, A., Berthier, L., Pommeret, B. and Serreau, R. (2017) Guidelines for Multivitamin Administration in Fortified Human Milk Prepared for Preterm Infants. Archives de Pédiatrie, 24, 107-111.

https://doi.org/10.1016/j.arcped.2016.11.003

[29] Palacios, C., Kostiuk, L.K. and Peña-Rosas, J.P. (2019) Vitamin D Supplementation for Women during Pregnancy. Cochrane Database of Systematic Reviews, 7, CD008873. https://doi.org/10.1002/14651858.CD008873.pub4

[30] Palacios, C., Trak-Fellermeier, M.A., Martinez, R.X., Lopez-Perez, L., Lips, P., Salisi, J.A., John, J.C. and Peña-Rosas, J.P. (2019) Regimens of Vitamin D Supplementation for Women during Pregnancy. Cochrane Database of Systematic Reviews. https://doi.org/10.1002/14651858.CD013446 


\section{Glossary}

AFSSA: French Agency for Sanitary Safety of Foods

AJR: Recommended Daily Contributions

ANSES: National Agency of Sanitary Security, Food, Environment, Work

DS: Dietary Supplement

CNGOF: French National College of Gynecologists-Obstetricians

CSP: Public Health Code

EPP: Early Prenatal Interview

BMI: Body Mass Index

INCA: National Individualized Study of Food Consumption

PNNS: National Health Nutrition Plan

PNP: Preparation for Birth and Parenthood

QCM: Multiple Choice Questionnaire 